\title{
The Impact of Covid-19 on the Creations of Fashion Designers
}

\author{
Ariana Gjoni \\ University for Business and Technology - UBT, Str.: Rexhep Krasniqi nr.56, 10000 Prishtina, Kosovo \\ *ariana.gjoni@ubt-uni.net
}

\begin{abstract}
The pandemic, known as Covid-19, is affecting the global economy causing an economic crisis. The nonessential product categories are the categories that have been hit extremely hard, and the fashion industry is also part of this category. This study was conducted to understand the impact of Covid-19 on the apparel industry, independent fashion designers, in different European countries. The study has found that the apparel industry is one of the most affected industries among the other industries by COVID-19. Many of the demands that have been made are already being considered. Independent designers find it difficult to provide good conditions for their workers and have lost the harmony of the chain of realization and the launch of their collections in the market. With declining sales, the existing stock of manufactured garments will be sold at low prices in the coming months. Many designers have suspended advertising for their creations - though some continue to use social media influencers to promote their products. The current environment, although challenging, presents an opportunity for a substantial and welcome change that will simplify businesses and, ultimately, align them more closely with customer needs.
\end{abstract}

Keywords: Covid 19, Crisis, Creations, Fashion Design

DOI: $10.7176 / \mathrm{ADS} / 92-01$

Publication date: April $30^{\text {th }} 2021$

\section{Introduction}

COVID-19 is spreading human suffering all over the world; this is what we are all focused on. But we are not all doctors, we are of different professions, yet we are all witnesses that Covid-19 is spreading economic suffering as well. Recent studies show that the virus can be as contagious economically as it is medical (Chadha \& Kapoor, 2010). The Coronavirus pandemic has caused major consequences in all sectors of the economy worldwide, and in recent months the world has witnessed how the COVID-19 pandemic has caused the most difficult crisis of modern business. The non-essential products are categories that have been hit extremely hard, and the fashion industry is also part of this category (Anner, 2020).

Hardly any industry has survived without being honored because of the pandemic. The magnitude of the pandemic impact was revealed by financial results published by well-known fashion brands. The impact on the industry was immediate, with governments around the world calling for an end to non-essential retail sales, including fashion (Chakraborty \& Biswas, 2020). Fashion councils are launching funds to support independent fashion businesses that now face an even more uncertain future as consumer spending on fashion continues to spiral (Bhardwaj \& Fairhurst, 2010).

The global Covid-19 pandemic has had a devastating impact on global clothing and textile supply chains. In this case, brands and retailers have reacted quickly by canceling or postponing orders and production, and as a result, millions of workers in this industry have been sent home (Black, 2020). Amongst the acts of kindness all over social media at the moment, small and independent fashion brands fighting for survival are also doing their part. The first reactions of the fashion industry to the covid-19 was from fashion houses donations to fashion weeks going digital. Donators: Prada, Dolce Gabbana, Versace, Giorgio Armani, Maison Valentino.

Among the first Western big-hitters to respond were Chanel and Armani. On February 17, Chanel announced they would no longer stage their Métiers d'Art collection in Beijing in May.

In February, Giorgio Armani canceled on his invitees less than 24 hours' notice, asking them to watch a live stream of the show instead.

The fashion industry is ruled by giants-mega-corporations from fast fashion to luxury titans, which between them owns brands including Louis Vuitton, Gucci, Dior, and Saint Lauren. These are publicity-traded companies with tens of billions in annual sales, and they make most of the industry's profits.

But they're not all there is. Fashion is also filled with a large number of smaller, independent companies with far more modest sales.

Independent designers often operate on tight budgets, using the sales from one collection to fund the next. Many still rely on selling wholesale to retailers for the bulk of their earnings and may sell just a few items straight to shoppers. Either way, any delays or disruptions in their sales can interrupt their cash flow and play havoc with the whole business (Sen, 2008). They may be unable to buy fabrics, pay manufacturers, or cover other bills, such as rent if they have a store.

This study aimed to understand the impact of Covid-19 on the apparel industry, independent fashion 
designers, in different European countries (Brydges, Heinze, Retamal, \& Henninger, 2020).

The main purpose of this study is to describe and predict the work of independent fashion designers, focusing on collections, orders, chain of realization, and launch of their collection, Important processes that help us to create an overview more approximate for the difficulties and possibilities of creating collections and requests of clients of independent designers in the new economic conditions created as a result of the situation caused by the pandemic Covid-19 (McMaster, 2020).

\section{Literature Review}

A crisis is an alarming notion; it is alarming when used in science, economics, health, and everyday life as well (Anner, 2020). Throughout history, the fashion industry has been affected by the crisis.

\subsection{The Great Depression}

Due to the stock market crash of 1929 left the style of fashion in the past, even though those years were known as the "roaring twenties", a decade full of fascination and expense. Cheap nylon fabrics began to be used because expensive materials were not affordable. On this occasion, women started to make their clothes, which means that all women were in fashion. All of this, lower prices, made businesses make clothes faster and cheaper, and the invention of the zip made it possible. Women needed clothes that were affordable, but that in a way were stylish. Despite this clash, the elegance and femininity of the 30s fashion were not lost. The cloche hat style and short hairstyle continued throughout the 1930s even into the early 1940s.

\subsection{World War II}

When the war broke out, clothing restrictions were imposed. This means that the materials were replaced and the range of clothes available was limited. In the United Kingdom, colors began to be shared; industry began to use red in clothing, green and brown in military uniforms. Laddered stockings became a cause for concern for women in the UK, so they started painting on stockings, even including the seam at the back!(Chakraborty \& Biswas, 2020).

With all the restrictions that were placed on, and with men in war, women began to make their clothes with unused clothes. The 'siren suit' became very popular during the war. Stylish additions were often made, including bell bottoms, puffed shoulders, and detachable belts. Although during the war the style became minimal, it was practical. The way of making clothes in this way was like escaping from reality and raising the moral of fashion, the creation of clothes with patriotic models and colors started.

\subsection{AIDS}

The AIDS crisis in 1980 shocked the fashion industry, and the dressing up of protests became popular to fight against inaction and reaction by governments. The fashion industry was very aware of how the crisis was affecting all creators within the industry. Kenneth Cole (an American clothing designer) launched a media campaign to reduce stigma, and Anna Wintour (a British-American journalist and editor who has been editor-inchief of Vogue) organized a gala evening for shopping, gathering 3 million dollars for AIDS research. Almost everyone in the fashion industry was affected by AIDS and crises continue to affect the industry even today.

\subsection{Great Recession}

People were dripping in gold. There was bling on clothing, jewelry, accessories" says Christina Binkley, who covered fashion for the Wall Street Journal." Fashion had been really loud, and it was a huge party, and then that shifted overnight". What happened was the Great Recession, which started in late 2007 and officially ended in June 2009, though many Americans are still feeling its effects today. Millions of people lost their jobs, and with so many consumers cutting back on spending, retailers got pummeled.

\section{Aim of research}

The study aims to understand the impact of the Covid 19 pandemic on the fashion industry, independent fashion stylists across different European countries. This was accomplished through interviewing independent designers and stylists across Europe.

The purpose of the research was to analyze the impact of the Covid 19 pandemic on the well-being of the fashion industry, where to achieve this I interviewed 6 designers from Europe. The research was conducted through a semi-structured interview.

\subsection{Research questions}

To achieve the goal, I posed research questions:

1. What was the impact of the Covid 19 pandemic on the well-being of the fashion industry in Europe?

2. To what extent has the pandemic affected business development? 
3. Did they have problems with the orders and how did they manage to fulfill them?

4. What is expected in the future for this industry?

\section{Methodology of Research}

The research is of qualitative type, based on the nature and sensitivity of the research topic the data are collected through a standardized interview which consists of ten questions. Through the careful structuring of the questions, we have received more detailed information about the experiences and dealing of designers-fashion designers with the economic crisis which has involved the whole world, relationships, and communication.

During the conduct of this research, the selection of correspondents represents an important criterion. To have a clearer picture of the current state of fashion designers, the selection of correspondents was done in four different European countries: England, the Netherlands, Germany, and Kosovo. Because these countries are considered as points on which we can compare the conditions and business environment in which designers from different countries work, also because of the diversity of designers. Besides, we have tried to select the correspondents based on several other criteria, which are:

\subsection{Brand participated-6}

From four different European countries: England, the Netherlands, Germany, and Kosovo, with the same professional training: Design, Fashion Design. Positions in the brands where they work: Creative Director / Founder; Owner/designer; CEO and designer of the brand; Co-Founder \& Managing Director location; Founder/director:

1. Luxury/high and handmade bespoke garments for men, Frankfurt-Germany.

2. Women's wear brand. It offers garments for special occasions, Prishtina-Kosovo.

3. Rugs and home furnishings, London- UK.

4. Exclusive collection of sustainable, limited items for businesswomen, Netherlands.

5. Sustainable men's and women's collection sold directly to the consumer through its online store, London-UK.

6. Cocktail and wedding dresses ready to wear and also customized, Prishtina-Kosovo.

4.2 Results of the Interview - first interpreting

\begin{tabular}{|c|c|c|}
\hline Question & First interpreting & Respondents answer \\
\hline 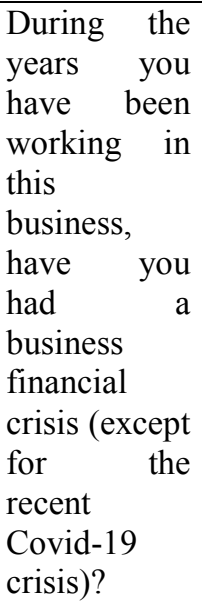 & $\begin{array}{l}\text { It is considered that the } \\
\text { Covid } 19 \text { crisis has } \\
\text { affected the normal well- } \\
\text { being of fashion } \\
\text { businesses. This is being } \\
\text { confirmed by the } \\
\text { interviewees where in } \\
\text { general the crisis has } \\
\text { affected their finances and } \\
\text { normal development. }\end{array}$ & $\begin{array}{l}\text { I1. Working in this business for big brands for the past } 14 \text { years, } \\
\text { there was never any financial crisis, except the financial crisis in } \\
2007 \text {. During our } 2 \text { years, we had a substantial increase month by } \\
\text { month. } \\
\text { I2. It is usually pretty stable except this time of Covid-19 that had a } \\
\text { significant impact on how the business develops. } \\
\text { I3. Yes, in the first year of the brand opening. } \\
\text { I4. No } \\
\text { I5. Yes, a big retail company had all my items on a consignment } \\
\text { basis and went in liquidity. I got it all back. } \\
\text { I6. Of course! Fashion is a big financial crisis! It needs a vast } \\
\text { amount of money to launch a brand and sustain it! }\end{array}$ \\
\hline
\end{tabular}




\begin{tabular}{|c|c|c|}
\hline destion & rst interpreting & swer \\
\hline $\begin{array}{l}\text { What do you } \\
\text { think about } \\
\text { the recent } \\
\text { crisis caused } \\
\text { by the } \\
\text { COVID-19 } \\
\text { pandemic, at } \\
\text { what level } \\
\text { did it hit } \\
\text { your } \\
\text { business? }\end{array}$ & $\begin{array}{l}\text { The crisis caused by the } \\
\text { Covid } 19 \text { pandemic has } \\
\text { affected many aspects of } \\
\text { fashion businesses. } \\
\text { According to the } \\
\text { interviewees, we consider } \\
\text { that the crisis has affected } \\
\text { from the first phase by } \\
\text { paralyzing the } \\
\text { development of business, } \\
\text { especially the movements } \\
\text { between countries were } \\
\text { impossible, and this has } \\
\text { automatically affected the } \\
\text { reduction of customers, } \\
\text { causing problems to well- } \\
\text { known brands. In some } \\
\text { cases, the pandemic did } \\
\text { not affect as this happened } \\
\text { due to the format of } \\
\text { businesses and forms of } \\
\text { doing business. }\end{array}$ & $\begin{array}{l}\text { I1. The pandemic disrupted our positive development, which was } \\
\text { very difficult to handle at the beginning of the pandemic because } \\
\text { there was no sign of how long it lasted. It has hit us on all sides. } \\
\text { Since our production is in Napoli (Italy), which was designated a } \\
\text { crisis area at the beginning of the pandemic, we were cut off in an } \\
\text { early stage. } \\
\text { I2. Covid-19 made the world behave completely differently. } \\
\text { Therefore, it caused changes to my business as well. It mainly } \\
\text { reduced the number of clients. } \\
\text { I3. This pandemic situation has caused our Brand a lot. By closing } \\
\text { the workshop, I got from } 6 \text { employers, now the shop is operating } \\
\text { only with one employer. And we work just by orders if there is } \\
\text { any. } \\
\text { I4. Fortunately, we have been largely unaffected as yet by the } \\
\text { crisis. We have experienced some slight delays in production and } \\
\text { deliveries, but these have been minimal. } \\
\text { I5. Especially because Drezzunique is, there for businesswomen, } \\
\text { there is far less demand for these kinds of products and people are } \\
\text { afraid to lose their jobs and are more careful to make investments. } \\
\text { I6. I stopped trading before Covid but speaking with other fashion } \\
\text { companies, they have been hot hard because people don't think } \\
\text { about fashion during times like this. }\end{array}$ \\
\hline $\begin{array}{l}\text { How did you } \\
\text { deal with the } \\
\text { orders which } \\
\text { you were not } \\
\text { able to fulfill } \\
\text { due to the } \\
\text { situation } \\
\text { created? }\end{array}$ & $\begin{array}{l}\text { During the pandemic, } \\
\text { fashion companies } \\
\text { stopped direct orders, in } \\
\text { some cases they were shut } \\
\text { down before quarantine } \\
\text { began to avoid risk. This } \\
\text { has normally affected } \\
\text { businesses to suffer huge } \\
\text { losses, which are } \\
\text { unpredictable. }\end{array}$ & $\begin{array}{l}\text { I1. It has hit and stopped all products. On one hand, the latest } \\
\text { orders could not be started, nor the pending orders could not be } \\
\text { even completed, they were in the final process. Some clients } \\
\text { canceled the order because they had to cancel their wedding too. } \\
\text { Additionally, we proposed to our clients a credit note for the } \\
\text { amount they've paid. } \\
\text { I2 We had to close entirely due to the Government's regulations. } \\
\text { Consequently, we stopped all the work in the atelier and delayed it } \\
\text { for an undefined time. } \\
\text { I3. Some of them were postponed for the next year, and most of } \\
\text { them were canceled. This means we had to return the down } \\
\text { payment. } \\
\text { I4. Our customers have really understood if they have experienced } \\
\text { short delays due to Covid, but these delays have been minimal. } \\
\text { I5. N/A } \\
\text { I6. Does not apply. }\end{array}$ \\
\hline
\end{tabular}




\begin{tabular}{|c|c|c|}
\hline Question & First interpreting & Respondents answer \\
\hline $\begin{array}{l}\text { As an } \\
\text { independent } \\
\text { designer, } \\
\text { how difficult } \\
\text { has it been to } \\
\text { provide good } \\
\text { working } \\
\text { conditions } \\
\text { for your } \\
\text { employees, } \\
\text { and have } \\
\text { you lost the } \\
\text { harmony of } \\
\text { the chain of } \\
\text { realization } \\
\text { and launch } \\
\text { of your } \\
\text { collections } \\
\text { in the } \\
\text { market? }\end{array}$ & & $\begin{array}{l}\text { I1. We were able to implement the rules prescribed to us very well } \\
\text { because our concept is designed for individual appointments, even } \\
\text { before the pandemic. The working conditions have been easy to } \\
\text { provide as we are not a typical store. In general, it was difficult to } \\
\text { activate our loyal customers and partners after relaxing regulations } \\
\text { from the government because the handling of the pandemic varies } \\
\text { from customer to customer. Some customers are paying attention } \\
\text { and some customers are afraid, which makes it difficult to retain } \\
\text { the clients. } \\
\text { I2. It wasn't difficult to provide good working conditions for my } \\
\text { workers, but we are facing difficulties in developing new } \\
\text { collections. } \\
\text { I3. Since we are not a big team, we had no problems with working } \\
\text { conditions since working space compere to the number of } \\
\text { employees is quite big, but the difficulty lies in the market demand. } \\
\text { And, of course, this chain has been broken since a month ago as we } \\
\text { struggled to create a new collection because of the incomes. } \\
\text { I4. As an independent designer who outsources much of our } \\
\text { products and other services as required, working conditions have } \\
\text { been maintained as normal in-house. We have, however, needed to } \\
\text { rethink our marketing strategy to launch new collections and are } \\
\text { placing more focus on B2C online retailing for future campaigns. } \\
\text { I5. Yes, it is very difficult in general. I wanted my collection to be } \\
\text { made in the Netherlands, and people to have normal salaries, so the } \\
\text { production facility I made use of was very expensive. This also } \\
\text { resulted in a high retail price (because all were limited editions), } \\
\text { and I could not reach the right customer who was willing to pay for } \\
\text { that. } \\
\text { I6. Can't answer this. }\end{array}$ \\
\hline $\begin{array}{l}\text { What about } \\
\text { the existing } \\
\text { stock, how } \\
\text { did you act, } \\
\text { did you } \\
\text { lower the } \\
\text { prices or did } \\
\text { you not do } \\
\text { such a thing? }\end{array}$ & $\begin{array}{l}\text { For some companies, the } \\
\text { work was done as it was } \\
\text { not too difficult, but it can } \\
\text { be said that it was difficult } \\
\text { to develop the collections } \\
\text { as contact with people was } \\
\text { limited or not at all. } \\
\text { In the case of freelance } \\
\text { designers, this has been } \\
\text { easier since the work has } \\
\text { been done from home. }\end{array}$ & $\begin{array}{l}\text { I1. Since all our products are individually manufactured, it does not } \\
\text { have any effect on our business. } \\
\text { We didn't change anything on our price structure. } \\
\text { I2. No, I did not make sales. } \\
\text { I3. Yes, of course, we made the sale and also made offers for our } \\
\text { customers, but this didn't work because they even like our product, } \\
\text { or the price is nice. Nowadays, nowadays the thing that costumer } \\
\text { byes, they prefer to wear it immediately, which this situation does } \\
\text { not offer this possibility. Since there are no events or events, } \\
\text { people don't want to spend money on things that they don't use. } \\
\text { Fashion is a very fast industry in which trends move very quickly. } \\
\text { That's why if they buy something today, they want to wear it } \\
\text { today. } \\
\text { I4. We did run successful short Summer Sale on stock items, but } \\
\text { generally, we are cautious about discounting and sales, as we do } \\
\text { not wish to lower our brand image. We also wish to ensure that we } \\
\text { maintain our B2B relationships with trade price offers that do not } \\
\text { compete with retail price offers. } \\
\text { I5. Yes, I lowered the prices so much there I cannot even have the } \\
\text { cost price. } \\
\text { I6. No. I don't and never believed in sales, by reducing your prices } \\
\text { you are de-valuing your brand! }\end{array}$ \\
\hline
\end{tabular}




\begin{tabular}{|c|c|c|}
\hline Question & First interpreting & Respondents answer \\
\hline $\begin{array}{l}\text { With sales } \\
\text { currently } \\
\text { low, have } \\
\text { you } \\
\text { continued to } \\
\text { use } \\
\text { advertising } \\
\text { or suspended } \\
\text { it for your } \\
\text { creations? }\end{array}$ & $\begin{array}{l}\text { They say that they have } \\
\text { done the advertising } \\
\text { continuously without any } \\
\text { change in their advertising } \\
\text { plan. Since this was not } \\
\text { possible before the } \\
\text { pandemic, the designers } \\
\text { say that this goes on } \\
\text { without any major } \\
\text { problems. }\end{array}$ & $\begin{array}{l}\text { I1. Despite the pandemic and the temporary lack of sales, we have } \\
\text { continued to pursue and implement our plan. The planned events } \\
\text { were set up even if it was a big challenge. We were also able to set } \\
\text { up the advertising outfits for our busts/mannequin. } \\
\text { I2. I continued almost the same way I managed my business and } \\
\text { creations in the past. } \\
\text { I3. Yes, this is something else that we tried, and from all that we } \\
\text { have benefitted from was being liked on social media and lovely } \\
\text { comments, which we assume that it might reflect in the future, but } \\
\text { not now. } \\
\text { I4. Our advertising has remained unchanged and remains } \\
\text { predominantly organic rather than via paid ads. } \\
\text { I5. No, I totally suspended the business. } \\
\text { I6. I was suspended over a year ago, but if I was trading, I would } \\
\text { have continued advertising differently, focused on the current } \\
\text { situation. I don't believe you can keep churning out the same } \\
\text { things when the world around you is changing. Brands have to } \\
\text { keep evolving if they want to stay current. }\end{array}$ \\
\hline $\begin{array}{l}\text { Have you } \\
\text { used social } \\
\text { media } \\
\text { influencers } \\
\text { to promote } \\
\text { your } \\
\text { products? }\end{array}$ & $\begin{array}{l}\text { Here designers and } \\
\text { companies have a divided } \\
\text { opinion, where some have } \\
\text { used but not in the long } \\
\text { run, while others consider } \\
\text { it a waste of money as this } \\
\text { does not fit the format of } \\
\text { their business and the } \\
\text { designs they offer in the } \\
\text { market. }\end{array}$ & $\begin{array}{l}\text { I1. No, and in general, we don't use influencers as brand } \\
\text { ambassadors because we believe in our strategy. Let's say the } \\
\text { traditional way that happy clients will be able to suggest us to other } \\
\text { potential clients. } \\
\text { I2. No, I don't choose to promote my designs through influencers } \\
\text { at all. Not in the past, nor during the pandemic. } \\
\text { I3. Yes, but it is something related to the type of the product. Our } \\
\text { product is not a pair of shoes or jeans or T-shirt that someone } \\
\text { would wear on a daily basis. Our product is for special occasions. } \\
\text { Even though you use social media influencers; it doesn't affect the } \\
\text { customer because it's a cycle. } \\
\text { The customer is not in the same situation as "she was" with the } \\
\text { income. And they try to be more careful in managing the cash. For } \\
\text { the ones that have the same incomes, they try to keep the cash } \\
\text { since no one knows what is going to happen. } \\
\text { I4. No. But we have collaborated with retail partners for product } \\
\text { giveaways, for example. } \\
\text { I5. I tried once but decided not to push through. } \\
\text { I6. Yes. They are only good if you have a fully circular marketing } \\
\text { strategy in place, otherwise, you are wasting your money! }\end{array}$ \\
\hline $\begin{array}{l}\text { As an } \\
\text { independent } \\
\text { designer, } \\
\text { have you } \\
\text { faced an } \\
\text { existential } \\
\text { crisis? }\end{array}$ & $\begin{array}{l}\text { It is considered that in this } \\
\text { state everything was } \\
\text { turbulent, but, fortunately, } \\
\text { they found ways to } \\
\text { survive. This is a new } \\
\text { opportunity to continue } \\
\text { with the development of } \\
\text { the business, hoping to } \\
\text { improve the situation in } \\
\text { general. Regardless of the } \\
\text { cases, this has had an } \\
\text { impact on everyone. }\end{array}$ & $\begin{array}{l}\text { I1. For sure there was always something that I've kept in mind and } \\
\text { started to calculate how things are going to be if the pandemic goes } \\
\text { on and how I can improve as the ongoing costs will be the same. } \\
\text { I2. I must say it is pretty hard to be in control right now, but I am } \\
\text { trying to do my best, use this time to develop myself, and work } \\
\text { responsibly. } \\
\text { I3. Not like this before. Fashion is a very wide industry, and I think } \\
\text { that some ranges can still exist and provide goods, but not luxury } \\
\text { goods. } \\
\text { I4. No. } \\
\text { I5. Yes, I stopped with Drezzunique. } \\
\text { I6. I have gone low for now, but I will come back to this industry } \\
\text { in the future. }\end{array}$ \\
\hline
\end{tabular}




\begin{tabular}{|c|c|c|}
\hline Question & irst interpreting & Respondents answer \\
\hline $\begin{array}{l}\text { Has the } \\
\text { government } \\
\text { of the } \\
\text { country } \\
\text { where you } \\
\text { operate, the } \\
\text { taken the } \\
\text { initiative to } \\
\text { provide } \\
\text { financial to } \\
\text { support to } \\
\text { fashion businesses? } \\
\text { busing }\end{array}$ & $\begin{array}{l}\text { They say that their } \\
\text { governments have helped } \\
\text { them, and that makes us } \\
\text { happy because the time we } \\
\text { all went through, not just } \\
\text { businesses, was difficult. } \\
\text { They are expressing } \\
\text { satisfaction with this help, } \\
\text { as it was at the right time } \\
\text { and moment. }\end{array}$ & $\begin{array}{l}\text { I1. In general, the government supported all businesses and fashion } \\
\text { too, some more, some less. } \\
\text { I2. The government did help all businesses, not specifically } \\
\text { something meant for the fashion industry. Even though helpful in } \\
\text { the time of crises, the financial support that is being given is not } \\
\text { nearly enough to operate. Since it is a very large industry in } \\
\text { Kosovo as well, I think it should be taken into consideration more } \\
\text { seriously. } \\
\text { I3. Yes, there were three times, which was not enough, that was the } \\
\text { minimum of the salary, not even enough for the rents... Which } \\
\text { means we had to close all the gaps by the very low incomes that we } \\
\text { had, and the rest was from our savings. And now also the savings } \\
\text { are finished, and that's why some of the brands collapse. } \\
\text { I4. There are many support initiatives in the UK, but they do not } \\
\text { support all business types. Fortunately, we have not needed to seek } \\
\text { government support. } \\
\text { I5. To a certain extend. I had access to a person who could help } \\
\text { with business advice during certain times. } \\
\text { I6. Our government has provided support for all industries. }\end{array}$ \\
\hline $\begin{array}{l}\text { Does the } \\
\text { current } \\
\text { environment, } \\
\text { although } \\
\text { challenging, } \\
\text { present an } \\
\text { opportunity } \\
\text { for a } \\
\text { substantial } \\
\text { and welcome } \\
\text { change for } \\
\text { fashion } \\
\text { businesses? }\end{array}$ & $\begin{array}{l}\text { The designers hope there } \\
\text { will be a big change for } \\
\text { the fashion business as the } \\
\text { pandemic has been } \\
\text { challenging for everyone. } \\
\text { In some cases, they say } \\
\text { that the pandemic should } \\
\text { never come again, as it has } \\
\text { had a very bad impact on } \\
\text { the development of their } \\
\text { business, but in general, } \\
\text { they are hoping for } \\
\text { positive changes. }\end{array}$ & $\begin{array}{l}\text { I1. Honestly, I hope there will be a huge change for the fashion } \\
\text { businesses in case of sustainability and more eco-friendly } \\
\text { production. The fashion and especially the fast fashion have been } \\
\text { on the peak in the last years, and as the name already says, } \\
\text { everything went too fast. From my perspective, the whole fashion } \\
\text { industry should change the way they produce and should not } \\
\text { produce several units of garments in a cheap way, which means } \\
\text { that the whole market is flooded with too much clothing and, as } \\
\text { mentioned, especially fast fashion. The future should be } \\
\text { sustainable and resourceful, based on existing materials, the } \\
\text { environment is not limitless. } \\
\text { I2. I wish the pandemic had never happened, but regarding fashion; } \\
\text { I think it was time for change. We must take a second look at how } \\
\text { we create, produce and communicate with our customers. } \\
\text { Undoubtedly, this time opened many doors to new thoughts, and it } \\
\text { is an opportunity to redesign ourselves and ourselves in this } \\
\text { industry. } \\
\text { I3. We don't see any change in this upcoming year, but we may try } \\
\text { to search for a new range of products (maybe more essential), } \\
\text { which will not consider a high risk of entering the market and } \\
\text { doesn't require a big investment. } \\
\text { I4. Yes, definitely. We hope that this crisis presents an opportunity } \\
\text { for people to reconsider their impact on the world. To question } \\
\text { their purchasing habits and needs, and to buy timeless products that } \\
\text { are created with sustainable practices and a low environmental } \\
\text { footprint. We believe products should have longevity and be } \\
\text { treasured for years - we hope that customers will continue to } \\
\text { move in this direction too and away from a fast and disposable way } \\
\text { of living. } \\
\text { I5. I think that there are too many fish in the sea and too much } \\
\text { stock, so I think that it has to be different. More eye for handwork } \\
\text { and exclusive items that last and are made consciously. } \\
\text { I6. Yes! When there is a crisis, there is also an opportunity! If a } \\
\text { brand is smart, it can rapidly gain market share in times like this. } \\
\text { Be innovative, carve out your niche, and respond quickly to } \\
\text { changes, and new creative brands will succeed. Unfortunately, } \\
\text { though, many independent brands unless they focus all their efforts } \\
\text { on online sales, will not make it. }\end{array}$ \\
\hline
\end{tabular}




\subsection{Final interpreting}

Business financial crisis

As a general conclusion from this paper, it turns out that the impact of the global financial crisis caused by the Covid 19 pandemic, is different in businesses coming from different countries. The financial crisis during the pandemic is precisely the financial stability of design companies. This is since they found it difficult to develop their brand in the normal way. This has affected the companies not to have financial stability, lack of development of their brand, and liquidity was a very important issue. Then at the beginning of the crisis, there was a lack of financial support as there was no information on how long it would last. However, there are some commonalities: the clothing trade has declined in all countries ranging from intermediate goods to final products. Interviewed brands had business financial crises even once, in the first year of the brand opening, during the Great Recession, in 2007, and most of them had a crisis during the lockdown caused by the pandemic Covid- 19 . Covid 19 pandemic level crisis

With consumers finding themselves at home and with a low commitment to clothing, sales have not been able to maintain the same pace for all businesses alike. The financial crisis for some businesses was at an alltime high, but not for everyone equally. It depended on the brand, the size of the business, and the form of business development. There had been a decrease in sales as a result of the impossibility of normal recovery although it had not been completely stopped. There were problems with workers at the beginning of the pandemic, but not then found solutions.

A crisis caused by the COVID-19 pandemic disrupted the positive development of brands and reduced the number of clients. Also, it caused the suspension of several employers.

Orders

Orders were initially canceled but then started with orders as well. But not everyone has had this opportunity as their brands are special orders, and for these special conditions were needed. They had some problems with loans, in the beginning, they had various cancellations after their partner businesses had started bankruptcies, and this also affects their companies. For orders and production, it was a big shock, the last orders could not be started and the pending orders could not even be completed though they were in the final process. Event cancellations triggered cancellations of porosity as well, which in rare cases were postponed to another date. As a result, the whole process was stopped and delayed indefinitely.

Work conditions and employees

Working conditions, brand development, and orders were automatically restricted through the Covid 19 pandemic crises. This affects the difficulty of communicating with customers, they were blocked, then they started limited cooperation. Access also started through virtual communication, as in some cases it was already a form of work, but it depended on how much and how the companies had their format. Difficulties are presented depending on the concept and budget that businesses operate. Working conditions have been closely linked to the creation of new collections, especially collections that have required different services in different countries. This chain of realization was broken causing difficulties in activating clients and because pandemic treatment varies from client to client.

Stock

In some cases, there had been no change, but it did not create difficulties in the usual work. This was since the pandemic had disabled normal access to stocks. Given that fashion is a fast-paced business, as there are rapid changes, this had created a crisis of orders from consumers. The condition caused by the pandemic also caused difficulties for clothing stocks. The only way to get rid of these bugs was to use seasonal discounts, but that didn't work. In some cases, fashion designers do not trust discounts too much because they do not want to downplay their brand image. Fashion is an industry where trends move very fast, and that is why if they buy something today, they want to wear it today.

Advertising

Advertising was not banned by any company, but it was reduced to the extent of their existence. It was carried out through normal media channels, but in some cases, social media was also used. This was considered to some extent a waste of time, but it was good to prove. Even if there has been an effort, the benefits of social media may be reflected in the future but not now.

Social media influencers

Social media is not considered an important element for the development of their brand, as this does not correspond to the format of their work. In some cases, it has been tried but was not considered adequate. It depends more on the type of product, the customer profile, the market level for which they design. It can function as part of a marketing strategy. In general, they don't choose to promote designs through influencers, sometimes it depends on the products they create, but not at the time of lockdown.

Existential crisis

There were times when companies and/or designers had vague opinions regarding their financial situation, but this, fortunately, did not last long. They had managed to develop their business to some extent, thus creating 
alternative ways for their brands to thrive. They have faced an existential crisis, but they admit that they didn't have a crisis like this before. Some of the brands stopped their activities, and they are hoping to come back to this industry in the future.

Government initiative

Governments had created funding opportunities, taking care of the existence of companies. We cannot say exactly how effective this was, but it certainly affected the improvement of the financial situation. In general, the government of different countries supported businesses in different ways. Germany supported all businesses and fashion too. In Kosovo the government did help all businesses, not specifically meant for the fashion industry, the financial support that is being given is not nearly enough to operate. The UK government has supported all industries. And designers from the Netherlands during a certain time had access to a person who could help with business advice.

Opportunity - change for fashion businesses

They consider that in the future they should be better prepared for the challenges, to create new conditions and opportunities for communication with their customers. This would affect the fashion business to be able to sustain itself and have better financial stability. Although challenging, the current environment presents an opportunity for a substantial and welcome change for the fashion industry.

\section{Conclusions}

The Covid 19 pandemic crises have also affected the fashion field, creating financial uncertainty, lack of support in its first steps, then brand development was problematic until businesses found alternative forms. The level of the crisis depended on the forms of doing business, so it depended on how the company had established the tradition of its operation, wherein in some cases it had affected an inability to do business, but in some cases, it was not felt at all.

The orders were a challenge faced by the fashion companies since at first, they had restrictions, cancellations and the cooperating companies had started bankruptcies. For this reason, at the beginning of the pandemic, fashion companies were directly challenged in their work.

Overcrowded stocks and their reduction with seasonal discounts in such a crisis do not work due to the rapid activities of this industry and the image of various brands.

Consumer spending coupled with the temporary closure of retail businesses has fallen sharply, and the decline in purchases has been immense.

Working conditions were minimized for many companies, but it was better for those who worked independently, without other workers, as the work was done from home. Stocks in some cases returned completely, and for most of them this had slowed down their sales, as access to customers was minimized.

The financial crisis had greatly frightened the fashion businesses, but they managed to do it in various forms. Their governments had also set up foundations or direct assistance to all businesses, and this was welcome, thus more or less alleviating their crisis.

This change and this economic upheaval which is very important for fashion designers and the industry in general promotes changes in brands and consumer behaviors that lead to changes in the fashion industry which will be more sustainable.

Despite the readiness and mobilization for change in the industry, the financial crisis caused by the influence of Covid-19 for independent fashion designers is posing new challenges for action (Kent 2020).

Fashion will continue to face an uncertain future, but tomorrow's industry will look very different from what we once knew.

There are hopes for huge changes in the case of sustainability and more eco-friendly production. It is an opportunity to redesign ourselves and ourselves in this industry. This crisis presents an opportunity for people to reconsider their impact on the world.

\section{Recommendations}

- $\quad$ To create more favorable financial conditions by governments to support the fashion business.

- $\quad$ To create suitable conditions for the development of brands also through information technology, so that consumers have access.

- $\quad$ To enable collaboration between fashion companies and marketing companies.

- $\quad$ Design processes to be reviewed in the light of COVID-19 to fundamentally analyze the industry and lead to a new system.

- Following the pandemic, high-quality products and sustainability will become more important to consumers, given the expected economic uncertainty.

- Brands to optimize their relationship with the customer by emphasizing ethical behavior and communication, adjusting their experience.

- $\quad$ Create awareness of the fragility of the flexible supply chain that depends on a single region. 
- $\quad$ To have a focus on deeper partnerships between brands and manufacturers.

- $\quad$ Companies need to partner with each other and build on their trusting relationship values. For many companies, the collaboration will be essential. next season.

- $\quad$ Rebuilding global supply chains will involve a brighter spotlight on trust and relationships, but also on the opportunities presented by technology.

- $\quad$ It is essential that fashion designers do not pause, but use the time to reflect, retrieve and rebuild a sustainable industry.

The next study provides an opportunity to examine how fashion designers, stylists, educational institutions and the apparel industry are responding to the current emergency.

\section{References}

Anner, M. (2020). Abandoned? The impact of Covid-19 on workers and businesses at the bottom of global garment supply chains. PennState Center for Global Workers' Rights (CGWR), 29.

Bhardwaj, V., \& Fairhurst, A. (2010). Fast fashion: response to changes in the fashion industry. The international review of retail, distribution and consumer research, 20, 165-173.

Black, S. (2020). Fashion in a Time of Crisis. Fashion in a Time of Crisis. Taylor \& Francis.

Brydges, T., \& Hanlon, M. (2020). Garment worker rights and the fashion industry's response to COVID-19. Dialogues in Human Geography, 10, 195-198.

Brydges, T., Heinze, L., Retamal, M., \& Henninger, C. E. (2020). Platforms and the pandemic: A case study of fashion rental platforms during COVID-19. The Geographical Journal.

Chadha, S. K., \& Kapoor, D. (2010). A study on knowledge management practices of auto component manufacturing companies in Ludhiana City. IUP Journal of Knowledge Management, 8, 68.

Chakraborty, S., \& Biswas, M. C. (2020). Impact of COVID-19 on the Textile, Apparel and Fashion Manufacturing Industry Supply Chain: Case Study on a Ready-Made Garment Manufacturing Industry. Apparel and Fashion Manufacturing Industry Supply Chain: Case Study on a Ready-Made Garment Manufacturing Industry (July 15, 2020).

Ditchfield, S., \& Delumeau, J. (2020). Coronavirus (COVID-19) impact. The catholic historical review, 106, 335-343.

Gereffi, G., \& Frederick, S. (2010). The global apparel value chain, trade and the crisis: challenges and opportunities for developing countries. The World Bank.

McMaster, M., Nettleton, C., Tom, C., Xu, B., Cao, C., \& Qiao, P. (2020). Risk management: rethinking fashion supply chain management for multinational corporations in light of the COVID-19 outbreak. Journal of Risk and Financial Management, 13, 173.

Şen, A. (2008). The US fashion industry: A supply chain review. International Journal of Production Economics, $114,571-593$.

Fernandes, N., 2020. Economic Effects of Coronavirus Outbreak (COVID-19) on the World Economy. SSRN Electronic Journal,

Chadha, D. (2021). The Impact of COVID-19 On the Fashion Design Industry. Retrieved 3 January 2021, from https://www.entrepreneur.com/article/350190

Indvic, L. (2020). Light after the lockdown - the future of fashion. Retrieved 15 December 2020, from https://www.ft.com/content/1b03efec-8895-11ea-a01c-a28a3e3fbd33

Kent, S. 2020. "Global Fashion Agenda Calls on Industry to Rebuild Sustainably." The Business of Fashion. Accessed 16 February 2021. HYPERLINK "https://www.businessoffashion.com/articles/newsanalysis/global-fashion-agenda-calls-on-industry-to-rebuild-sustainably" It "blank" https://www.businessoffashion.com/articles/news-analysis/global-fashion-agenda-calls-on-industry-torebuild-sustainably 